\title{
Filament winding process for kenaf fibre reinforced polymer composites
}

\begin{abstract}
In this chapter, a study on filament winding process for kenaf fibre reinforced polymer composite manufacture is presented. Filament winding process for conventional fibre composites is discussed. Advantages and disadvantages of filament winding process are also briefly covered. A review on filament winding from various research is also performed. Brief review of filament winding of natural fibre composites is provided. The chapter also describes work on improvement of existing filament winding process and fabrication of hollow shaft made from kenaf fibre reinforced composites. The main contribution was the use of drum-type resin bath and surfacing veil, and these had facilitated ease of fabrication of kenaf yarn fibre reinforced unsaturated polyester composite hollow shafts.
\end{abstract}

Keyword: Filament winding; Natural fibre composites; Kenaf; Biocomposites; Hollow shafts 